Check for updates

Cite this: RSC Adv., 2017, 7, 43950

Received 3rd August 2017

Accepted 6th September 2017

DOI: 10.1039/c7ra08607e

rsc.li/rsc-advances

\section{Fluorescent triazolium for sensing fluoride anions in semi-aqueous solution $\dagger$}

\author{
Bin-Yong Wang, ${ }^{a}$ Zhi-Qiang Chen, ${ }^{a}$ Hongwei Huang ${ }^{\mathrm{b}}$ and Qian-Yong Cao (D) *a \\ A new pyrene-appended triazolium has been synthesized and explored as a highly efficient receptor for \\ fluoride anions. In an $\mathrm{CH}_{3} \mathrm{CN}-\mathrm{H}_{2} \mathrm{O}$ competitive solution, this probe shows an exclusive fluorescence \\ turn-off sensing of $\mathrm{F}^{-}$over other anions. ${ }^{1} \mathrm{H}$ NMR titrations and density functional theory (DFT) \\ calculations revealed that the triazolium $(\mathrm{CH})^{+}$, sulfonamide $\mathrm{NH}$ and pyrenyl $\mathrm{CH}$ donors were involved in \\ hydrogen bonding interactions with a $\mathrm{F}^{-}$anion to form a stable $1-\mathrm{F}^{-}$complex. In addition, the probe \\ was successfully applied to the detection of $\mathrm{F}^{-}$from inorganic origins in the solid state.
}

\section{Introduction}

The development of chemosensors for the sensing and recognition of fluoride anions has been of growing interest for the past few decades due to its crucial role in biosystems. ${ }^{1-3}$ Fluoride is an essential element for the body. Appropriate fluoride ingestion can prevent dental cavities and osteofluorosis. ${ }^{\mathbf{4} 5}$ However, chronic exposure to high levels of fluoride causes severe diseases such as dental and skeletal fluorosis, kidney and gastric disorders, and urolithiasis in humans., ${ }^{6,7}$ Therefore, sensitive and accurate detection of fluoride anions in environmental and biological system is in high demand.

Until now, many analytical methods including inductively coupled plasma, atomic emission spectrometry, atomic absorption spectroscopy, electrochemical methods, absorption and emission spectroscopy have been reported for detection of fluoride anion. ${ }^{\mathbf{8 - 1 2}}$ Among them, the fluorescent technique has been attracted particular attention for its low-cost, high sensitivity and easy operation. ${ }^{13-17}$ Thus, many fluorescent fluoride probes based on different interaction mechanisms, including hydrogen bonding, ${ }^{18-23}$ Lewis acid complexation ${ }^{24-28}$ and desilylation reaction, ${ }^{29-33}$ have been developed. Owing to the smallest size and high hydration enthalpy $\left(-505 \mathrm{~kJ} \mathrm{~mol}^{-1}\right)$ of fluoride anion in aqueous solution, ${ }^{34}$ the complexation and sensing of fluoride anion in aqueous media is mainly limited in the fluoride anion-induced chemical reactions systems. Hydrogen bonding type sensors are only capable of sensing $\mathrm{F}^{-}$ in pure organic solvent, or in the presence of a small amount of water, which often suffer interference from alkaline anions such

\footnotetext{
${ }^{a}$ Department of Chemistry, Nanchang University, Nanchang 330031, P. R. China. E-mail: cqyong@ncu.edu.cn; Fax: +86-791-83969514

${ }^{b}$ College of Chemistry and Bio-engineering, Yichun University, Yichun 336000, P. R. China

$\dagger$ Electronic supplementary information (ESI) available. CCDC 1566968. For ESI and crystallographic data in CIF or other electronic format see DOI: 10.1039/c7ra08607e
}

as $\mathrm{AcO}^{-}$and $\mathrm{H}_{2} \mathrm{PO}_{4}{ }^{-} \cdot{ }^{35-38}$ In addition, most of these probes can detect tetrabutylammonium fluoride (TBAF) rather than inorganic fluoride such as KF. ${ }^{39,40}$

Recently, the click derived triazolium has attracted much attention in anions supramolecular chemistry because of its specific $(\mathrm{C}-\mathrm{H})^{+} \cdots$ anion hydrogen bond interaction. ${ }^{41-43}$ Several groups, including ours, have used triazolium as a platform for anions recognition. ${ }^{\mathbf{4 4 - 5 1}}$ Thus, a series of triazolium-based probe for fluorescence sensing of $\mathrm{F}^{-}, \mathrm{H}_{2} \mathrm{PO}_{4}{ }^{-}$and other anions have been well established in organic solution. However, systems for $\mathrm{F}^{-}$recognition with high selectivity in aqueous solution were still rare. Herein, we report a new fluorescence triazolium 1 (Scheme 1) for anions recognition. With the pyrene as the fluorescence signal moiety, the triazolium $(\mathrm{CH})^{+}$and sulfonamide $\mathrm{NH}$ as the hydrogen bonding donors, probe $\mathbf{1}$ shows an exclusive fluorescence turn-off sensing of inorganic fluoride anion $\mathrm{KF}$ in $\mathrm{CH}_{3} \mathrm{CN}-\mathrm{H}_{2} \mathrm{O}(9: 1, \mathrm{v} / \mathrm{v})$ solution. The binding mechanism between probe $\mathbf{1}$ and $\mathrm{F}^{-}$was investigated in detail by various spectral techniques (UV-vis, fluorescence and ${ }^{1} \mathrm{H}$ NMR) and DFT calculations.

\section{Results and discussion}

The synthetic route of the target probe $\mathbf{1}$ was shown in Scheme 1 . The precursors 1- $N$-(2-propynyl)pyrene sulfonamide (2) and benzyl azide (3) were first prepared by the literature methods. ${ }^{50,52}$ Click reaction compounds 2 and 3, the neutral triazole 4 was then synthesized. Alkylation of 4 with $(\mathrm{MeO})_{3} \mathrm{BF}_{4}$ in $\mathrm{CH}_{2} \mathrm{Cl}_{2}$ solution obtained the triazolium probe 1 with high yield ( $82 \%$ yield). The chemical structure of $\mathbf{1}$ was fully characterized by ${ }^{1} \mathrm{H}$ NMR, ${ }^{13} \mathrm{C}$ NMR, TOF-ESI-MS and the X-ray single crystal analysis.

The single crystals of $\mathbf{1}$ were obtained by slow diffusion hexane into its dichloromethane solution. In the X-ray crystal structure of 1 (Fig. 1), the whole structure of the probe adopts a fold conformation. The pyrene ring is roughly parallel to 
Scheme 1 Synthesis route of 1. (a) $\mathrm{CuSO}_{4} \cdot 5 \mathrm{H}_{2} \mathrm{O}, \mathrm{NaVc}, \mathrm{DMF}, 2 \mathrm{~h}$, rt. (b) $\left(\mathrm{Me}_{3} \mathrm{O}\right) \mathrm{BF}_{4}, \mathrm{DCM}, \mathrm{rt}, 3$ days.

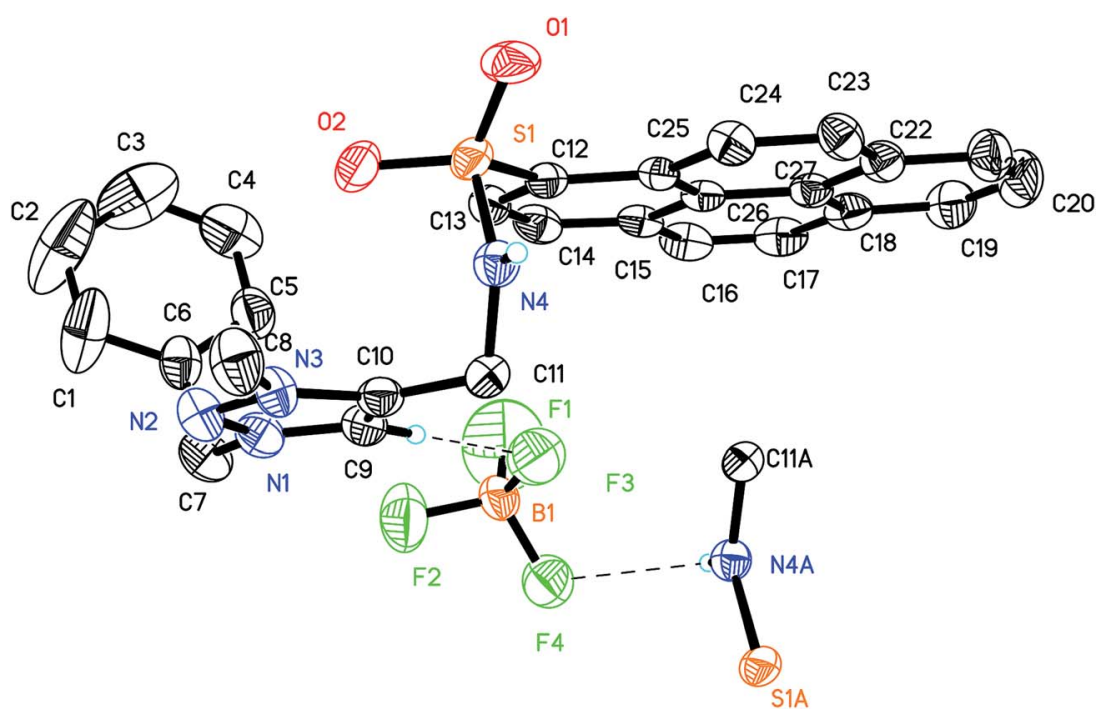

Fig. 1 X-ray structure of 1 . All the hydrogen atoms except sulfonamide $\mathrm{NH}$ and triazolium $(\mathrm{CH})^{+}$were omitted for clarity.

$\left(4.3(2)^{\circ}\right)$ the triazolium ring, but is nearly vertical $\left(71.4(3)^{\circ}\right)$ to the benzene ring. The two anions binding sites, sulfonamid $\mathrm{NH}$ and triazolium $(\mathrm{CH})^{+}$, show an anti conformation in the solid state of $\mathbf{1}$, and are involved in hydrogen bonding with the $\mathrm{BF}_{4}{ }^{-}$

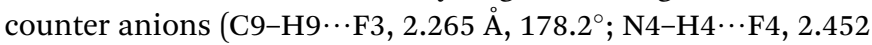
$\AA$, $134.2^{\circ}$, symm code: $2-x, 1-y, 1-z$ ). In addition, $\pi-\pi$ interaction (3.435 $\AA$ ) between the intermolecular pyrene rings is found in the crystal packing structure (Fig. S1†), which is further stabilized the X-ray structure of $\mathbf{1}$ in the solid state.

The recognition ability of 1 toward various anions $\left(\mathrm{F}^{-}, \mathrm{Cl}^{-}\right.$, $\mathrm{Br}^{-}, \mathrm{I}^{-}, \mathrm{AcO}^{-}, \mathrm{H}_{2} \mathrm{PO}_{4}{ }^{-}, \mathrm{CN}^{-}, \mathrm{NO}_{3}{ }^{-}$) in their potassium salts was firstly investigated by emission spectra in $\mathrm{CH}_{3} \mathrm{CN}-\mathrm{H}_{2} \mathrm{O}(9: 1, \mathrm{v} / \mathrm{v})$ solution. With excitation at $360 \mathrm{~nm}$, probe 1 showed a strong structured pyrene-based monomer emission at $382 \mathrm{~nm}$ (Fig. 2). Upon the addition of $\mathrm{F}^{-}$( 6 equiv.), the emission of probe 1 exhibited a large quenching effect (90\% quenching), which can be easily observed from strong blue emission to dark quenching by the naked eyes. The large emission changes of $\mathbf{1}$ upon addition $\mathrm{F}^{-}$may be attributed to the strong hydrogen bonding interaction between 1 and $\mathrm{F}^{-}$. Thus, the forming $1-\mathrm{F}^{-}$complex enhances photoinduced electron transfer quenching (PET) from the electron rich $\mathrm{F}^{-}$anion to the excited state of the pyrene fluorophore. ${ }^{53,54}$ In contrast, the addition of other anions induced the emission of $\mathbf{1}$ barely changes, including the basic $\mathrm{AcO}^{-}$and $\mathrm{H}_{2} \mathrm{PO}_{4}{ }^{-}$anions, which often show interference of the
$\mathrm{F}^{-}$probes. Thus, probe $\mathbf{1}$ can be used as a fluorescence sensor for $\mathrm{F}^{-}$in semi-aqueous solution.

Fig. 3 shows the fluorescence spectra changes of 1 with the incremental addition of KF. With increasing the concentration

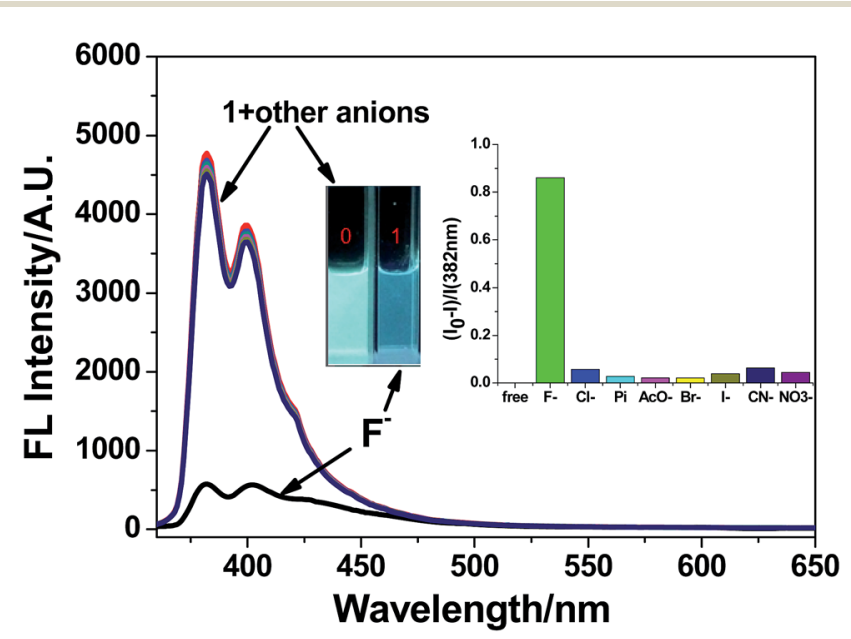

Fig. 2 Fluorescence spectra of $1\left(2.0 \times 10^{-5} \mathrm{M}\right)$ before and after addition 6 equiv. of anions (the form of potassium salts)in $\mathrm{CH}_{3} \mathrm{CN}-$ $\mathrm{H}_{2} \mathrm{O}(9: 1, v / v)$ solution, $\lambda_{\text {exi }}=360 \mathrm{~nm}$. Inset: the bar graph of 1 at $382 \mathrm{~nm}$ upon addition of anions. 


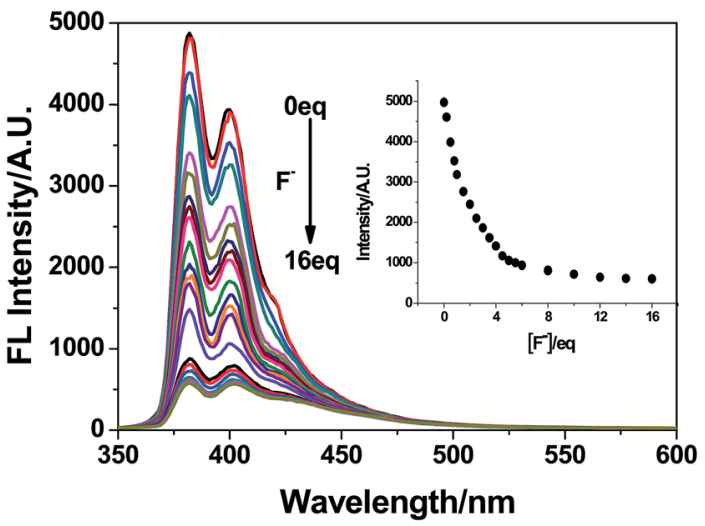

Fig. 3 Fluorescence spectra of $1\left(2.0 \times 10^{-5} \mathrm{M}, \lambda_{\text {ex }}=360 \mathrm{~nm}\right)$ upon the addition of $\mathrm{F}^{-}$in $\mathrm{CH}_{3} \mathrm{CN}-\mathrm{H}_{2} \mathrm{O}(9: 1, \mathrm{v} / \mathrm{v})$ solution. Inset: fluorescence titration curve of 1 at $382 \mathrm{~nm}$ versus the equivalence of $\mathrm{F}^{-}$.

of $\mathrm{F}^{-}$, the pyrene-based emission of $\mathbf{1}$ at $382 \mathrm{~nm}$ gradually decreases, and was saturated when about 6.0 equivalence of $\mathrm{F}^{-}$ was added. The binding data between $\mathbf{1}$ and $\mathrm{F}^{-}$was investigated by the emission titration data. A $1: 1$ binding stoichiometry of the $1-\mathrm{F}^{-}$complex was determined from the Job's plot (Fig. S2 $\dagger$ ). Using the Benesi-Hildebrand equation, ${ }^{55}$ the binding constant $K_{\mathrm{a}}$ of the $1-\mathrm{F}^{-}$was calculated to be $1.6 \times 10^{3} \mathrm{M}(R=0.998$, Fig. S3 $\uparrow$ ). Importantly, the fluorescence intensity of 1 at $382 \mathrm{~nm}$ versus the concentrations of $\mathrm{F}^{-}$was in a linear manner with the concentration range from $0 \mu \mathrm{M}$ to $12 \mu \mathrm{M}$ (Fig. S4 $\dagger$ ). A detection limit of $39 \mathrm{nM}$ for $\mathrm{F}^{-}$was estimated for $\mathbf{1}$, which is much lower than the maximum limit of fluoride ion in drinking water (1.5 ppm, $79 \mu \mathrm{M}$ ) suggested by the World Health Organization (WHO). ${ }^{56}$

The UV-vis spectra changes of $\mathbf{1}$ before and after addition of anions were also investigated. Probe 1 shows typical pyrene-based bands at $348 \mathrm{~nm}, 357 \mathrm{~nm}$ and $378 \mathrm{~nm}$. Upon the addition of $\mathrm{F}^{-}$, the intensity of these bands decreases with $\mathrm{a} \sim 2 \mathrm{~nm}$ blue shift (Fig. 4), indicating a strong interaction between $\mathbf{1}$ and $\mathrm{F}^{-}$. Four clear isosbestic points at $331 \mathrm{~nm}, 363 \mathrm{~nm}, 376 \mathrm{~nm}$ and

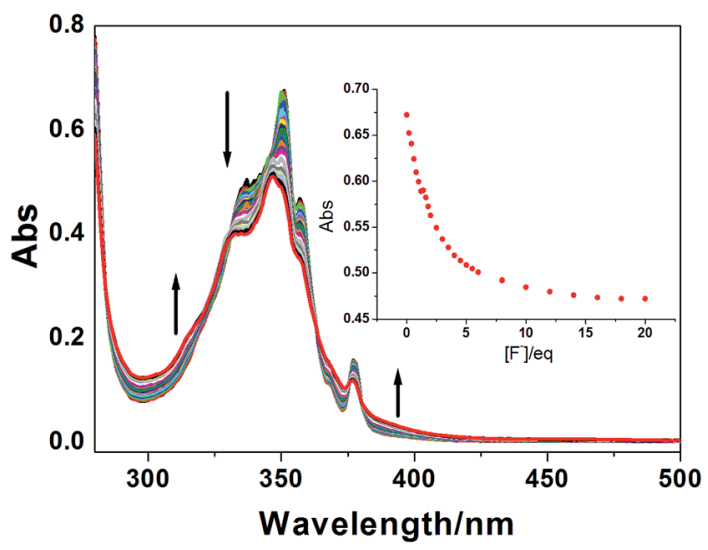

Fig. 4 UV-vis spectra of $1\left(2.0 \times 10^{-5} \mathrm{M}\right)$ upon addition various amount of $\mathrm{F}^{-}$in $\mathrm{CH}_{3} \mathrm{CN}-\mathrm{H}_{2} \mathrm{O}(9: 1, \mathrm{v} / \mathrm{v})$ solution. Inset: UV-vis titration curve of 1 upon the addition of $\mathrm{F}^{-}$at $349 \mathrm{~nm}$.
$380 \mathrm{~nm}$ were observed upon addition of $\mathrm{F}^{-}$, which imply that only one complex species forms during the complexation. In contrast, the addition of other anions induced no UV-vis spectra changes (Fig. S5 $\dagger$ ), even with a large amount. These results are well in accordance with the emission titration results.

The exclusive UV-vis and emission spectra response of $\mathbf{1}$ toward the strong basic anion $\mathrm{F}^{-}$may be attributed to the existing multiple hydrogen bonding between 1 and $\mathrm{F}^{-}$. Therefore, the ${ }^{1} \mathrm{H}$ NMR titration experiments of 1 with progressive addition of $\mathrm{F}^{-}$were carried out both in $\mathrm{CD}_{3} \mathrm{CN}$ and $\mathrm{CD}_{3} \mathrm{CN}-\mathrm{D}_{2} \mathrm{O}$ ( $9: 1, \mathrm{v} / \mathrm{v}$ ) solutions (Fig. 5). For solubility problem, TBAF was used instead of $\mathrm{KF}$ here. In $\mathrm{CD}_{3} \mathrm{CN}$ solution, the two typical anion binding donors, triazolium proton $\mathrm{Ha}$ and sulfonamide proton $\mathrm{Hb}$ in $\mathbf{1}$, were located in $7.03 \mathrm{ppm}$ and $6.49 \mathrm{ppm}$, respectively. Upon the addition of $\mathrm{F}^{-}$, the triazolium $(\mathrm{CH})^{+}$ proton leaded about a $0.13 \mathrm{ppm}$ down-filed shift (from $7.03 \mathrm{ppm}$ to 7.16 ppm, when 4.0 equiv. $\mathrm{F}^{-}$was added), while the sulfonamide proton disappeared quickly, implying strong hydrogen bonding between these two donors and $\mathrm{F}^{-}$anion. Interesting, a large down-filed shift was also observed in the $\alpha$-position proton of the pyrene ring ( $\mathrm{Hc}$, from $8.89 \mathrm{ppm}$ to $9.19 \mathrm{ppm}, \Delta \delta=$ $0.30 \mathrm{ppm}$ ), indicating that this $\mathrm{CH}$ proton may also be an additional anion binding donor for the electron withdrawing group sulfonamide. Neutral $\mathrm{CH} \cdots$ anion hydrogen bond was often observed in the aryl $\mathrm{CH}$ group when electron withdrawing substituents were present. ${ }^{57}$

The ${ }^{1} \mathrm{H}$ NMR titrations of 1 to $\mathrm{F}^{-}$in $\mathrm{CD}_{3} \mathrm{CN}-\mathrm{D}_{2} \mathrm{O}(9: 1, \mathrm{v} / \mathrm{v})$ solution were a little different from that in pure $\mathrm{CD}_{3} \mathrm{CN}$ solution. The sulfonamide proton $\mathrm{Hb}$ of free probe 1 disappeared for the deuterium exchange with $\mathrm{D}_{2} \mathrm{O}$. Upon the addition of $\mathrm{F}^{-}$, this proton was observed at $5.46 \mathrm{ppm}$ and increased with increasing the concentration of $\mathrm{F}^{-}$. Simultaneously, an obvious down-filed shift was found in protons $\mathrm{Ha}(\Delta \delta=0.14 \mathrm{ppm})$ and $\mathrm{Hc}(\Delta \delta=0.06 \mathrm{ppm})$ with addition of $\mathrm{F}^{-}$. These results revealed that the three protons, $\mathrm{NH},(\mathrm{CH})^{+}$and pyrenyl $\mathrm{CH}$ donors, still show strong hydrogen bonding interaction with $\mathrm{F}^{-}$in this competitive solvent, as that in pure $\mathrm{CD}_{3} \mathrm{CN}$ solution.

The multiple hydrogen bonding interactions between $\mathbf{1}$ and $\mathrm{F}^{-}$ were further confirmed by the DFT calculations. The optimized structure of $1-\mathrm{F}^{-}$complex in gas phase is shown in Fig. 6. In the presence of $\mathrm{F}^{-}$, the sulfonamid and triazolium donors prefers a syn conformation rather than anti conformation by rotation to form an electropositive cavity for the anions. According to the suggested geometry cutoffs for $\mathrm{D}-\mathrm{H} \cdots \mathrm{A}$ hydrogen bond definition, ${ }^{\mathbf{5 8 , 5 9}}$ the sulfonamide proton, the triazolium proton, the $\alpha$-position pyrene proton and even the $\alpha$ position phenyl proton are involved hydrogen bonding chelating with $\mathrm{F}^{-}$anion, with the $\mathrm{H}^{\cdots} \mathrm{F}^{-}$hydrogen bonding distance values of $1.53 \AA$, $1.54 \AA$ A $1.95 \AA$ and $2.28 \AA$, respectively. According to the $\mathrm{H}^{\cdots} \mathrm{F}^{-}$bond distance, the anions binding ability of these donors follows the order, $\mathrm{NH} \sim(\mathrm{CH})^{+}>$pyrenyl $\mathrm{CH}>$ phenyl $\mathrm{CH}$, which is in accordance with ${ }^{1} \mathrm{H}$ NMR titration results. Thus, these multiple hydrogen bonding interactions make 1 tightly bind with $\mathrm{F}^{-}$anion, even in $\mathrm{CD}_{3} \mathrm{CN}-\mathrm{D}_{2} \mathrm{O}$ competitive solvent condition.

The competition experiments were then carried out to investigate the selectivity and anti-interference of the probe $\mathbf{1}$ 


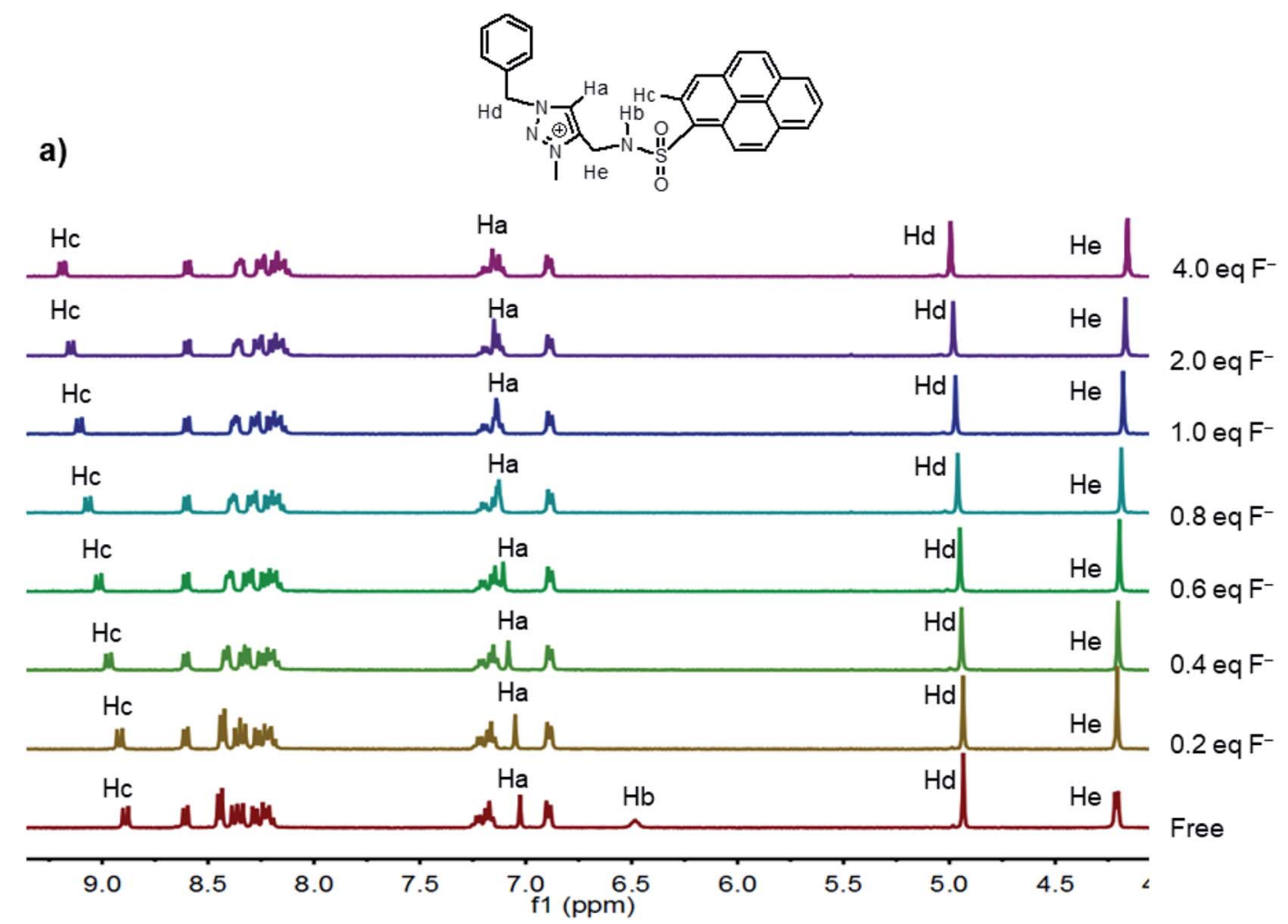

b)

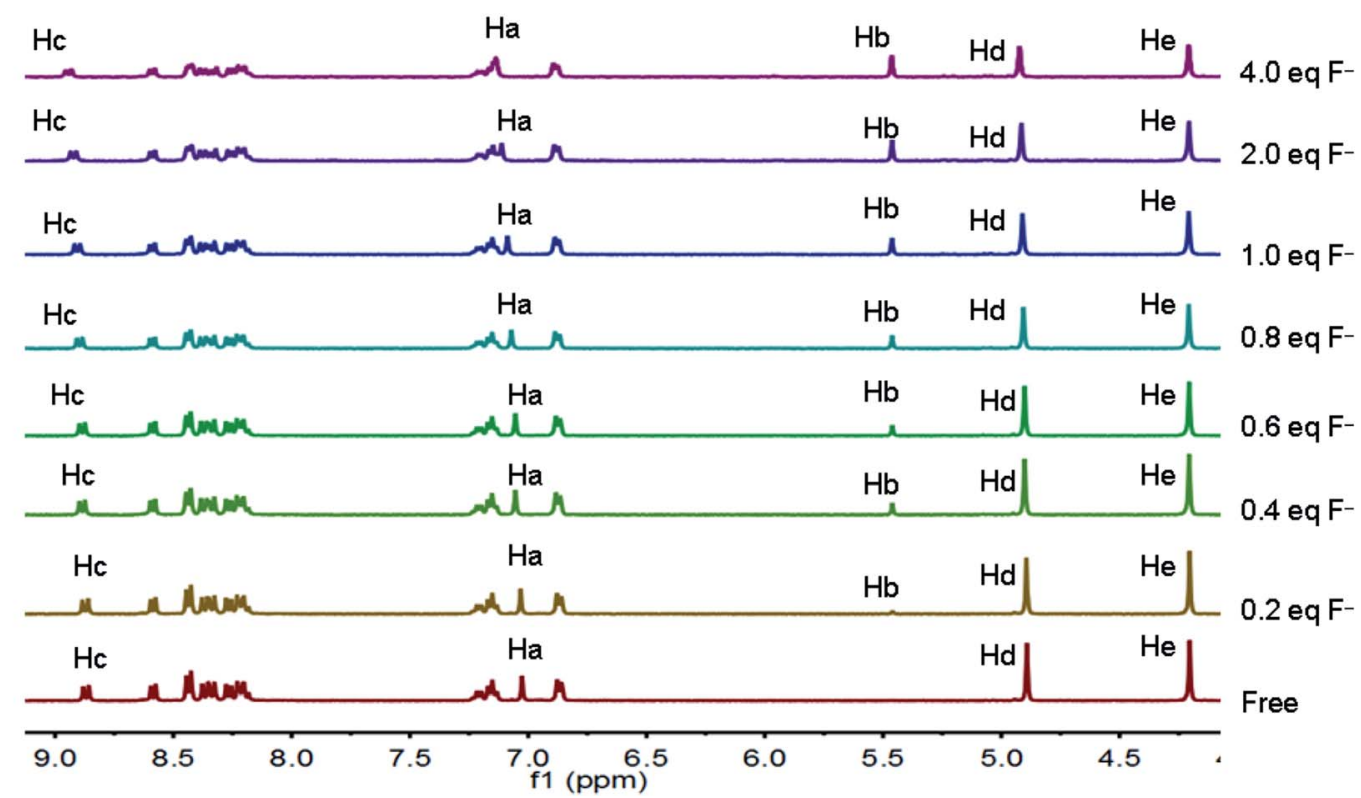

Fig. $5{ }^{1} \mathrm{H}$ NMR spectra of 1 (4.0 mM) before and after addition various amount of TBAF (0-4.0 equiv.) in $C D_{3} C N(a)$ and $C D_{3} C N-D_{2} O(9: 1, v / v)$ (b) solutions.

for $\mathrm{F}^{-}$anion detection. The fluorescence changes of 1 at $382 \mathrm{~nm}$ by adding various anions $\left(\mathrm{Cl}^{-}, \mathrm{Br}^{-}, \mathrm{I}^{-}, \mathrm{NO}_{3}{ }^{-}, \mathrm{H}_{2} \mathrm{PO}_{4}{ }^{-}, \mathrm{CN}^{-}\right.$and $\mathrm{AcO}^{-}$) and then addition of $\mathrm{F}^{-}$in $\mathrm{CH}_{3} \mathrm{CN}-\mathrm{H}_{2} \mathrm{O}(90: 10 \mathrm{v} / \mathrm{v})$ solution are shown in Fig. 7. There is no significant changes in the fluorescence spectra compared with that observed by the addition of $\mathrm{F}^{-}$alone, indicating that probe $\mathbf{1}$ exhibits excellent selectivity toward fluoride anion and good anti-interference ability against other coexisting anions.

Furthermore, the potential practical applicability of probe $\mathbf{1}$ in solid state for detection of $\mathrm{F}^{-}$was also investigated according to the method in the literature. ${ }^{60,61} \mathrm{~A} \mathrm{CH}_{3} \mathrm{CN}$ solution of 1 (0.5 mM) was dropped onto the Whatman filter paper and dried 


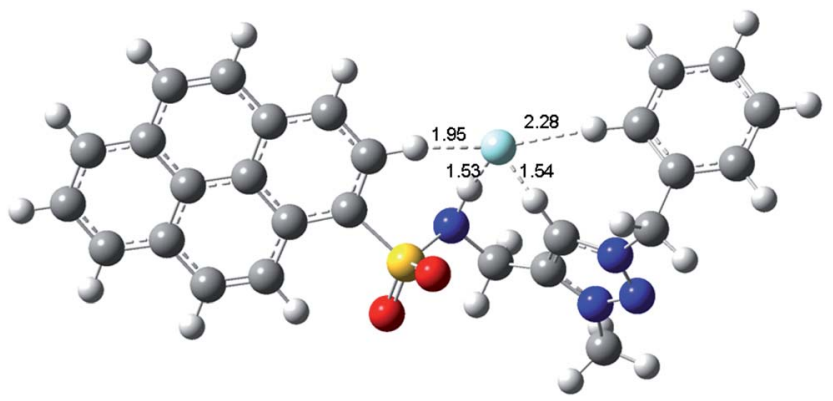

Fig. 6 Calculated structure (B3LYP/6-31G*) of 1. $\mathrm{F}^{-}$complex.

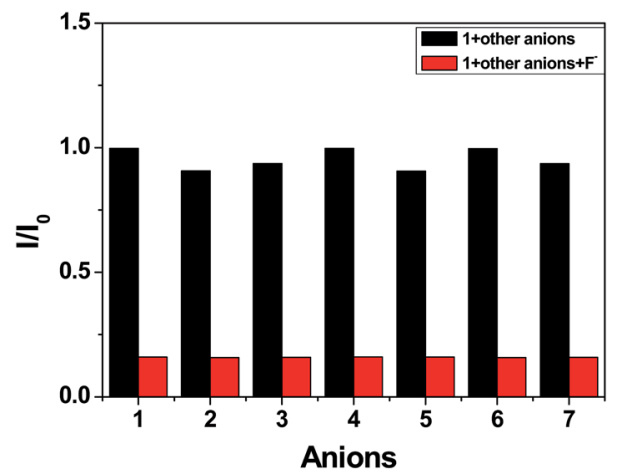

Fig. 7 The fluorescence intensity of 1 at $382 \mathrm{~nm}$ upon addition 6.0 equivalence of other anions (black bar) and then addition $\mathrm{F}^{-}$(red bar) in $\mathrm{CH}_{3} \mathrm{CN}-\mathrm{H}_{2} \mathrm{O}\left(90: 10\right.$, v/v) solution. (1) $\mathrm{Cl}^{-}$, (2) $\mathrm{H}_{2} \mathrm{PO}_{4}^{-}$, (3) $\mathrm{AcO}^{-}$, (4) $\mathrm{Br}^{-},(5) \mathrm{CN}^{-},(6) I^{-},(7) \mathrm{NO}_{3}^{-}$.

in the air, a strong blue fluorescent spot was observed, indicating the probe has a good disperse in the filter paper matrix, and then suppress the aggregation-caused quenching (ACQ) of the probe. However, when a spot of $\mathrm{F}^{-}$solution was added to the test kits (Fig. 8a), the strong blue spot change to the dark quenching. However, the addition of other competitive anions leads no response of the fluorescence. In addition, a thin layer chromatography (TLC) plate experiment also investigated by the literature methods (Fig. 8b). The same fluorescence response from strong blue emission to dark quenching was also observed
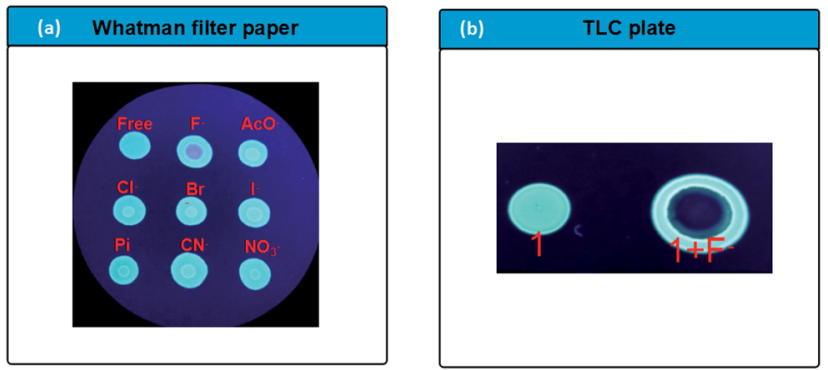

Fig. 8 (a) Photographic image of anion $\left(10^{-2} M\right)$ detection by 1 on filter paper tested by simple drop and dry from solutions of 1 and anions, consecutively. The sample was irradiated by UV-light (wavelength $365 \mathrm{~nm}$ ). (b) Fluorescence image (under $365 \mathrm{~nm}$ UV light) of probe 1 adsorbed on a TLC plate with a spot of KF solution on probe 1 . upon interaction with $\mathrm{F}^{-}$. Thus, probe $\mathbf{1}$ can detect $\mathrm{F}^{-}$in solid state not only by solution-coated TLC, but also using paper strips.

\section{Conclusion}

In conclusion, we have been successfully designed and synthesized a pyrene based anion receptor $\mathbf{1}$ bearing triazolium and sulfonamide donors. Probe 1 shows fluorescence turn-off sensing of inorganic $\mathrm{F}^{-}(\mathrm{KF})$ in $\mathrm{CH}_{3} \mathrm{CN}-\mathrm{H}_{2} \mathrm{O}$ competitive solution, and can detect it at the parts per million level. The ${ }^{1} \mathrm{H}$ NMR titration experiments proposed that the triazolium $(\mathrm{CH})^{+}$, the sulfonamide $\mathrm{NH}$ and even the pyrenyl $\mathrm{CH}$ donors play an important role to form a stable $1: 1$ stoichiometry $1-\mathrm{F}^{-}$ complex, which is further confirmed by the DFT calculations. Furthermore, this probe was successfully applied as a solid state optical sensor for detection of $\mathrm{F}^{-}$. Considering the good selectivity and sensitivity of probe $\mathbf{1}$ for the detection of $\mathrm{F}^{-}$in aqueous system, these novel findings will give important information for designing more sophisticated sensors for fluoride anion.

\section{Experimental section}

\section{General instrumentations and reagents}

All the starting materials for synthesis were commercially available and used as received. The solvents used for UV-vis and emission measurements were purified by standard procedures. 1- $N$-(2-Propynyl)pyrene sulfonamide (2) and benzyl azide (3) were prepared by the literature method. ${ }^{50,52}$

UV-vis spectra were recorded on a Hitachi UV-3010 spectrophotometer. Emission spectra were recorded on a Hitachi F4500 spectrophotometer. The excitation and emission slit width $(5 \mathrm{~nm})$ and the scan rate $\left(250 \mathrm{mV} \mathrm{s}^{-1}\right)$ were kept constant for all of the experiments. NMR spectra were recorded using a Varian instrument $(400 \mathrm{MHz})$ in DMSO- $d_{6}$ (Brucker, Switzerland; ${ }^{1} \mathrm{H}$ NMR $400 \mathrm{MHz},{ }^{13} \mathrm{C}$ NMR $101 \mathrm{MHz}$ ). HR MS were recorded using LC/MSD TRAP XCT Plus (1200 Agilent). The anions are potassium salts.

\section{Synthesis of 4}

A mixture of 1-N-(2-propynyl)pyrene sulfonamide $2(127 \mathrm{mg}$, $0.45 \mathrm{mmol})$, benzyl azide $3(67 \mathrm{mg}, 0.5 \mathrm{mmol}), \mathrm{CuSO}_{4} \cdot 5 \mathrm{H}_{2} \mathrm{O}$ $(25 \mathrm{mg}, 0.1 \mathrm{mmol})$ and sodium ascorbate $(40 \mathrm{mg}, 0.2 \mathrm{mmol})$ were dissolved in $4 \mathrm{~mL}$ DMF solution. The mixture was stirred at room temperature for $4 \mathrm{~h}$ under nitrogen atmosphere. Then $30 \mathrm{~mL} \mathrm{H}_{2} \mathrm{O}$ was added to get the precipitate. The solid was filtered, and purified by silica gel column chromatography using $\mathrm{CH}_{2} \mathrm{Cl}_{2}: \mathrm{CH}_{3} \mathrm{OH}(95: 5, \mathrm{v} / \mathrm{v})$ as the eluent to get 4 as a white powder $(176 \mathrm{mg}$, yield $87 \%) .{ }^{1} \mathrm{H}$ NMR $(400 \mathrm{MHz}$, DMSO$\left.d_{6}, \delta \mathrm{ppm}\right): 8.93(\mathrm{~s}, 1 \mathrm{H}), 8.64(\mathrm{~s}, 1 \mathrm{H}), 8.58-8.17(\mathrm{~m}, 8 \mathrm{H}), 7.64(\mathrm{~d}$, $J=9.1 \mathrm{~Hz}, 1 \mathrm{H}), 7.21(\mathrm{~s}, 3 \mathrm{H}), 7.02(\mathrm{~s}, 2 \mathrm{H}), 5.24(\mathrm{~d}, J=9.2 \mathrm{~Hz}, 2 \mathrm{H})$, $4.5(\mathrm{~s}, 2 \mathrm{H}), 4.10(\mathrm{~s}, 2 \mathrm{H}) .{ }^{13} \mathrm{C}$ NMR $\left(101 \mathrm{MHz}, \mathrm{CDCl}_{3} / \mathrm{CD}_{3} \mathrm{OD}\right.$, $\delta \mathrm{ppm}): 134.0,133.7,132.6,132.4,131.6,130.8,126.8,57.47$, 41.82. HR-MS (APCI) $m / z$ : calcd for $\mathrm{C}_{26} \mathrm{H}_{20} \mathrm{~N}_{4} \mathrm{O}_{2} \mathrm{~S}:$ 453.1384; found 453.1379 . 


\section{Synthesis of 1}

Under a nitrogen atmosphere, $275 \mathrm{mg}(0.5 \mathrm{mmol}) 4$ and $300 \mathrm{mg}$ (2.0 mmol) $\left(\mathrm{Me}_{3} \mathrm{O}\right) \mathrm{BF}_{4}$ was dissolved in $10 \mathrm{~mL} \mathrm{CH}_{2} \mathrm{Cl}_{2}$ and stirred at room temperature for three days. Then $2 \mathrm{~mL} \mathrm{MeOH}$ was added to quench the reaction. The organic solvent was removed under a vacuum pressure. The solid residue was then purified by silica gel column chromatography $\left(\mathrm{CH}_{3} \mathrm{OH}: \mathrm{CH}_{2} \mathrm{Cl}_{2}\right.$ $=1: 9, \mathrm{v} / \mathrm{v})$ to give 1 as a yellow solid (171 mg, $82 \%$ yield). ${ }^{1} \mathrm{H}$ NMR (400 MHz, DMSO- $d_{6}, \delta$ ppm): $8.93(\mathrm{~s}, 1 \mathrm{H}), 8.64(\mathrm{~s}, 1 \mathrm{H})$, 8.58-8.17 (m, 8H), $7.64(\mathrm{~d}, J=9.1 \mathrm{~Hz}, 1 \mathrm{H}), 7.21(\mathrm{~s}, 3 \mathrm{H}), 7.04(\mathrm{~s}$, 1H), $7.02(\mathrm{~s}, 2 \mathrm{H}), 5.24(\mathrm{~d}, J=9.2 \mathrm{~Hz}, 2 \mathrm{H}), 4.5(\mathrm{~s}, 2 \mathrm{H}), 4.10(\mathrm{~s}, 2 \mathrm{H})$. ${ }^{13} \mathrm{C}$ NMR (101 MHz, DMSO- $\left.d_{6}, \delta \mathrm{ppm}\right): 144.1,136.1,134.3$, $132.9,130.9$, 130.4, 129.8, 129.0, 128.4, 128.2, 127.6, 127.5, 127.3, 127.2, 127.1, 52.9, 38.3. HR-MS (APCI): $\mathrm{m} / \mathrm{z}$ : calcd for $\left[\mathrm{C}_{27} \mathrm{H}_{23} \mathrm{~N}_{4} \mathrm{O}_{2} \mathrm{~S}\right]^{+}:$467.1542; found 467.1527.

\section{General UV-vis and emission spectra measurements in solution}

Stock solutions of anions in their potassium salts $(0.1 \mathrm{M})$ were prepared in aqueous solution. Stock solution of receptor 1 (0.1 M) was prepared in $\mathrm{CH}_{3} \mathrm{CN}$ solution. The concentration of $\mathbf{1}$ in the UV-vis and emission titrations was $2.0 \times 10^{-5} \mathrm{M}$ in $\mathrm{CH}_{3} \mathrm{CN}-$ $\mathrm{H}_{2} \mathrm{O}(9: 1, \mathrm{v} / \mathrm{v})$ solution. During the titration, the anions stock solutions were added into a solution of $\mathbf{1}$ by a micro injector. The whole volume of the final system can be considered constant because the volume of anions solution added is negligible compared to that of receptor's solution.

\section{Calculation of the association constant and the detection limit (LOD)}

The binding constant of $\mathbf{1}-\mathrm{F}^{-}$was obtained from the fluorescence titration data using the Benesi-Hildebrand equation:

$$
\frac{1}{I-I_{0}}=\frac{1}{I^{\prime}-I_{0}}+\frac{1}{K\left(I^{\prime}-I_{0}\right)[\text { guest }]}
$$

where $I_{0}$ is the intensity of fluorescence of $\mathbf{1}$ without $\mathrm{F}^{-}, I$ is the intensity with a particular concentration of $\mathrm{F}^{-}, I^{\prime}$ is the intensity of the fully complexed form at the highest concentration of $\mathrm{F}^{-}$, and $K$ is the binding constant.

The LOD was calculated using the formula $3 \delta / k$ using the emission titration data, where $\delta$ was the standard deviation of blank (10 samples) and $k$ was the slope between intensity difference versus sample concentration.

\section{Detection of $\mathrm{F}^{-}$on solid state under UV light}

The $\mathrm{CH}_{3} \mathrm{CN}$ solution of $\mathbf{1}(0.5 \mathrm{mM})$ was first dropped to a piece of Whatman filter paper, and dried at room temperature for $4 \mathrm{~h}$. The obtained fluorescence spots was then dropped anions (0.5 mM in aqueous solution) using a micropipette. After drying the strips under vacuum, the results were observed with $365 \mathrm{~nm}$.

Thin-layer chromatography (TLC, spectrochem GF254 silica gel-coated plates) photo was also obtained by the similar method of Whatman filter paper.

\section{Calculation method}

Geometries of $\mathbf{1}$ and $\mathbf{1}-\mathrm{F}^{-}$complexation were optimized by DFT (B3LYP) method. A 6-31G(d, p) was selected for C, H, O, S and N atoms. No imaginary frequencies were available after vibration analysis of the optimized structures, which implied that the optimized structure was at the real minimum on the potential energy surfaces (PES). All the calculations were performed using Gaussian 09 program package.

\section{Crystallography}

Single-crystal X-ray diffraction measurements were collected on a Brucker CCD diffractometer using a graphite amonochromated Mo $\mathrm{K} \alpha$ radiation $(\lambda=0.71069 \AA)$ at $296(2) \mathrm{K}$. Intensity data were collected in the variable $\omega$-scan mode. The structures were solved by direct methods and refined on $F^{2}$ by using full-matrix least-squares methods with the SHELXL-97 program package. All non-hydrogen atoms were located in successive difference Fourier syntheses and refined with anisotropic thermal factors. The hydrogen atoms were introduced geometrically.

\section{Conflicts of interest}

There are no conflicts to declare.

\section{Acknowledgements}

This work was supported by the National Nature Science Foundation of China (no. 21462027 and 21762028).

\section{References}

1 Y. Zhou, J. F. Zhang and J. Yoon, Chem. Rev., 2014, 114, 55115571.

2 M. Cametti and K. Rissanen, Chem. Soc. Rev., 2013, 42, 20162038.

3 N. Busschaert, C. Caltagirone, R. W. Van and P. A. Gale, Chem. Rev., 2015, 115, 8038-8155.

4 J. R. Farley, J. E. Wergedal and D. J. Baylink, Science, 1983, 222, 330-332.

5 M. Kleerekoper, Endocrinol. Metab. Clin. North Am., 1998, 27, 441-452.

6 P. P. Singh, M. K. Barjatiya, S. Dhing, R. Bhatnagar, S. Kothari and V. Dhar, Urol. Res., 2001, 29, 238-244.

7 K. L. Kirk, Biochemistry of the elemental halogens and inorganic halides, NewYork Plenum Press, 1991.

8 M. M. Bayón, A. R. Garcia, A. J. I. García and S. M. Alfredo, Analyst, 1999, 124, 27-31.

9 G. Heike, W. Bernhard and W. E. Jürgen, Spectrochim. Acta, Part B, 2010, 65, 864-869.

10 V. Sunitha and B. M. Reddy, Int. J. Curr. Res. Acad. Rev., 2014, 2, 159-166.

11 A. M. Bond and T. A. O'Donnell, Anal. Chem., 1968, 40, 560563.

12 U. Nina, Anal. Chim. Acta, 2000, 417, 201-209. 
13 L. E. Santos-Figueroa, M. E. Moragues, E. Climent, A. Agostini, R. Martínez-Máñez and F. Sancenón, Chem. Soc. Rev., 2013, 42, 3489-3513.

14 X. Li, X. Gao, W. Shi and H. Ma, Chem. Rev., 2014, 114, 590659.

15 L. Gai, J. Mack, H. Lu, T. Nyokong, Z. Li, N. Kobayashi and Z. Shen, Coord. Chem. Rev., 2015, 285, 24-51.

16 P. A. Gale and C. Caltagirone, Coord. Chem. Rev., 2017, DOI: 10.1016/j.ccr.2017.05.003.

17 J. Wu, B. Kwon, W. Liu, E. V. Anslyn, P. Wang and J. S. Kim, Chem. Rev., 2015, 115, 7893-7943.

18 P. Ashokkumar, H. Weihoff, W. Kraus and K. Rurack, Angew. Chem., Int. Ed., 2014, 53, 2225-2229.

19 Q.-Y. Cao, M. Li, L. Zhou and Z.-W. Wang, RSC Adv., 2014, 4, 4041-4046.

20 V. Amendola, G. Bergamaschi, M. Boiocchi, L. Fabbrizzi and L. Mosca, J. Am. Chem. Soc., 2013, 135, 6345-6355.

21 S. Biswas, M. Gangopadhyay, S. Barman, J. Sarkar and N. P. Singh, Sens. Actuators, B, 2016, 222, 823-828.

22 J. Liu, X. He, J. Zhang, T. He, L. Huang, J. Shen and S. Yin, Sens. Actuators, B, 2015, 208, 538-545.

23 X. Zheng, W. Zhu, D. Liu, H. Ai, Y. Huang and Z. Lu, ACS Appl. Mater. Interfaces, 2014, 6, 7996-8000.

24 F. Cheng, E. M. Bonder and F. Jakle, J. Am. Chem. Soc., 2013, 135, 17286-17289.

25 S. Madhu and M. Ravikanth, Inorg. Chem., 2014, 53, 16461653.

26 M. Hirai and F. P. Gabbaï, Chem. Sci., 2014, 5, 1886-1893.

27 I. S. Ke, M. Myahkostupov, F. N. Castellano and F. P. Gabbaï, J. Am. Chem. Soc., 2012, 134, 15309-15311.

28 C. R. Wade, A. E. J. Broomsgrove, S. Aldridge and F. P. Gabbaï, Chem. Rev., 2010, 110, 3958-3984.

29 K. Dhanunjayarao, V. Mukundam and K. Venkatasubbaiah, Sens. Actuators, B, 2016, 232, 175-180.

30 D. Kim, S. Singha, T. Wang, E. Seo, J. H. Lee, S. J. Lee and K. H. Ahn, Chem. Commun., 2012, 48, 10243-10245.

31 M. E. Jun, B. Roy and K. H. Ahn, Chem. Commun., 2011, 47, 7583-7601.

32 L. Li, Y. Ji and X. Tang, Anal. Chem., 2014, 86, 10006-10009.

33 X. Chen, T. Leng, C. Wang, Y. Shen and W. Zhu, Dyes Pigm., 2017, 141, 299-305.

34 J. L. Sessler, P. A. Gale and W. S. Cho, Anion Receptor Chemistry, RSC Publishing, 2006.

35 V. B. Bregović, N. Basarić and K. Mlinarić-Majersk, Coord. Chem. Rev., 2015, 295, 80-124.

36 Y.-L. Xu, C.-T. Li, Q.-Y. Cao, B.-Y. Wang and Y. Xie, Dyes Pigm., 2017, 139, 681-687.

37 N. Kumari, S. Jha and S. Bhattacharya, J. Org. Chem., 2011, 76, 8215-8222.
38 L. Zhou, X. T. Fan, Y. D. Xu and Q.-Y. Cao, New J. Chem., 2015, 39, 8087-8092.

39 G. Sivaraman and D. Chellappa, J. Mater. Chem. B, 2013, 1, 5768-5772.

40 T. Anand, G. Sivaramana, M. Iniya, A. Siva and D. Chellappa, Anal. Chim. Acta, 2015, 876, 1-8.

41 B. Schulze and U. S. Schubert, Chem. Soc. Rev., 2014, 43, 2522-2571.

42 R. Tepper, B. Schulze, M. Jäger, C. Friebe, D. H. Scharf, H. Görls and U. S. Schubert, J. Org. Chem., 2015, 80, 31393150.

43 Y. Hua and A. H. Flood, Chem. Soc. Rev., 2010, 39, 1262-1271.

44 B. Sui, B. Kim, Y. Zhang, A. Frazer and K. D. Belfield, ACS Appl. Mater. Interfaces, 2013, 5, 2920-2923.

45 R. K. Chhatra, A. Kumar and P. S. Pandey, J. Org. Chem., 2011, 76, 9086-9089.

46 B. Schulze, C. Friebe, M. D. Hager, W. Günther, U. Köhn, B. O. Jahn and U. S. Schubert, Org. Lett., 2010, 12, 2710-2713.

47 A. Caballero, F. Zapata, L. González, P. Molina, I. Alkorta and J. Elguero, Chem. Commun., 2014, 50, 4680-4682.

48 Z.-C. Wang, Z. Wang, Q.-Y. Cao, S. Lin and Z.-W. Wang, ChemPlusChem, 2016, 81, 406-413.

49 Q.-Y. Cao, Y.-M. Han, P.-S. Yao, W. F. Fu, Y. Xie and J.-H. Liu, Tetrahedron Lett., 2014, 55, 248-251.

50 J.-Z. Ge, Z. Liu, Q.-Y. Cao, Y. Chen and J. H. Zhu, Chem.-Asian J., 2016, 11, 687-690.

51 Q.-Y. Cao, T. Pradhan, M. H. Lee, K. No and J. S. Kim, Analyst, 2012, 137, 4454-4457.

52 S. B. Nallapati, B. Y. Sreenivas, R. Bankala, K. V. L. Parsa, S. Sripelly, K. Mukkanti and M. Pal, RSC Adv., 2015, 5, 94623-94628.

53 R. M. Duke, E. B. Veale, F. M. Pfeffer, P. E. Kruger and T. Gunnlaugsson, Chem. Soc. Rev., 2010, 39, 3936-3953.

54 T. Gunnlaugsson, H. D. P. Ali, M. Glynn, P. E. Kruger, G. M. Hussey, F. M. Pfeffer, C. M. G. dos Santos and J. Tierney, J. Fluoresc., 2005, 15, 287-299.

55 N. J. Turro, Modern molecular photochemistry, Benjamin Cummings Publishing Co. Inc., Menlo Park, CA, 1978.

56 H. T. Dean, F. A. Arnold Jr, P. Jay and J. W. Knutson, Public Health Rep., 1950, 1403.

57 J. J. Cai and J. L. Sessler, Chem. Soc. Rev., 2014, 43, 61986213.

58 T. Steiner and G. R. Desiraju, Chem. Commun., 1998, 891892.

59 T. Steiner, Angew. Chem., Int. Ed., 2002, 41, 48-76.

60 Y. C. Wu, J. P. Huo, L. Cao, S. Ding, L. Y. Wang, D. Cao and Z. Y. Wang, Sens. Actuators, B, 2016, 237, 865-875.

61 J. F. Xiong, J. X. Li, G. Z. Mo, J. P. Huo, J. Y. Liu, X. Y. Chen and Z. Y. Wang, J. Org. Chem., 2014, 79, 11619-11630. 